\title{
Changes of plant species composition in the Šumava spruce forests, SW Bohemia, since the 1970s ${ }^{\text {ts }}$
}

\author{
Jan Wild $^{\mathrm{a}}$, Zdenka Neuhäuslováa ${ }^{\mathrm{a}}{ }^{*}$, Jaromír Sofron $^{\mathrm{b}}$ \\ anstitute of Botany, Academy of Sciences of the Czech Republic, CZ-252 43 Prühonice near Prague, Czech Republic \\ ${ }^{\mathrm{b}}$ West-Bohemian Museum, Kopeckého sady 2, CZ-300 00 Plzeñ, Czech Republic
}

Received 3 September 2001; received in revised form 30 January 2003; accepted 27 June 2003

\begin{abstract}
Vegetation dynamics of three forest communities were studied by resampling of relevés recorded in the 1970s in the Bohemian Forest (Šumava Mountains). Results of multivariate analysis (RDA) confirmed significant time changes in species composition of the climax (Calamagrostio-Piceetum) and waterlogged (Bazzanio-Piceetum) spruce forests. The changes in the sphagnum-rich waterlogged spruce forests (Sphagno-Piceetum) are close to the level of significance. The main vegetation changes are represented by a decrease in cover and/or frequency of hygrophilous or sciophilous species (e.g. Athyrium distentifolium, Oxalis acetosella) in climax spruce forests, and an abundant increase of species, indicating a preference to drier stands or better light conditions (e.g. Calamagrostis villosa, Vaccinium vitis-idaea or Avenella flexuosa), in waterlogged spruce forests. We also found a higher proportion of meadow species (e.g. Anthoxanthum odoratum, Festuca rubra or Luzula multiflora) in the newly recorded relevés from waterlogged forests. Analysis of species number per plot showed a remarkable shift to species-rich communities, especially in waterlogged stands.

We tried to find the possible factors responsible for the observed changes. Unfortunately, only indirect measurement of environmental factors using Ellenberg's indicator values could be used and did not yield sufficient results. Thus, the changes observed in climax spruce forests were ascribed mainly to a decrease in canopy cover, which was directly estimated. In waterlogged forests, a complex of several general factors, which influence the climax spruce forest, had to be taken into account, such as: (i) a decrease in atmospheric acidification during the last 10-15 years and subsequent improvement in soil conditions, especially in waterlogged stands; (ii) fragmentation of forests as a result of bark-beetles attack; (iii) climate warming documented by long-term local meteorological measurements.
\end{abstract}

(C) 2003 Elsevier B.V. All rights reserved.

Keywords: Vegetation dynamics; Time changes; Bohemian Forest; Czech Republic

\section{Introduction}

The dynamics of forest communities, which are highly endangered in some areas of the Czech Repub-

\footnotetext{
For nomenclature of vascular plants, see Ehrendorfer (1973), for bryophytes Frahm and Frey (1992), and for lichens Poelt (1969).

* Corresponding author. Tel.: +42-27-101-5245;

fax: +42-26-775-0031.

E-mail address: neuhauslova@ibot.cas.cz (Z. Neuhäuslová).
}

lic, have been studied with respect to environmental changes. Spruce stands of the Bohemian Forest (Šumava Mountains) have recently fallen into this category.

These studies have been carried out in Scandinavia where forests cover a major part of the area (cf. Bohn et al., 2000) and paying particular attention to spruce and pine stands (see, e.g. Brakenhielm and Persson, 1980; Engelmark et al., 1998; Hofgaard, 1993; 
Økland, 1994, 1995; Økland and Eilertsen, 1996). Most studies have followed the impact of air pollution on changes in the occurrence and abundance of plants. Detailed attention has also been paid to changes in species composition in the ground layer that plays an important role in these forests (cf. Økland, 1995; Lähde and Nieppola, 1987; Nygaard and Ødegaard, 1999). In the Czech Republic, on spruce and sprucebeech forest (Vacek and Lepš, 1991, 1992) changes due to the emission impact on $\mathrm{N}$ Bohemia were closely followed.

The Bohemian Forest has been a target of frequent phytocoenological research since the 1920s. The first studies were mainly dedicated to non-forest vegetation (mires, mat-grass meadows). Since the end of the 1950s, valuable forest communities were also studied, and later followed by other vegetation types (see Sofron, 1969, 1984). Recent biological, hydrological and forest research is concentrated mostly in the area of the Šumava National Park and the results published in the journal Silva Gabreta, Vimperk. Though many studies have been devoted to the spruce forest vegetation of Bohemian Forest (e.g. Sofron, 1981; Kučera in Pecharová and Rada, 1995; Sofron and Štěpán, 1971; Jirásek, 1996; Neuhäuslová and Eltsova, 2001, 2002), no study has analysed vegetation changes in this area.

In 1999, research on the diversity and dynamics of the spruce stands in the Bohemian Forest started. The character of the mountains, which were described at the beginning of the 1990s as a "more-or-less continuous island of forests" (Hladilin, 1996) changed significantly in some places during subsequent years. Significant damage and destruction of vast forest areas occurred in the central frontier part of the Bohemian Forest, especially in the area of large spruce plantations surrounding the villages of Kvilda and Modrava, gamekeeper's house at Březník, the water reservoir at Roklanská nádrž and Lusen Mountain. Even-aged plantations of spruce, sometimes of unknown origin, are unable to resist to air pollution, snowbreaks and windfall following bark-beetle attack (mostly Ips typographus and other species of xylophagous insects). These disturbances are among the causes of diminishing forest stands, not only in the Bohemian Forest (Zelenková et al., 2000), but also in other mountains of the republic.

The aim of this contribution is to consider (1) the extent of the changes in species composition in three types of the spruce forests, particularly in the Šumava National Park and the adjoining part of the Šumava Landscape Protected Area, from the 1970s to present, and (2) the causes of these changes.

\section{Material and methods}

\subsection{Study area}

The study area includes all of the Šumava National Park (68 064 ha) and the adjoining part of the Šumava Protected Landscape Area in the northwest, i.e. the Královský Hvozd ridge, including the Pancî́r and Můstek mountains in the northwestern frontier part of the Bohemian Forest on the southwestern border of the Czech Republic (see Fig. 1). This area is formed by Moldanubicum rocks (paragneisses and migmatites prevailing) and moldanubicum pluton represented by several broader granite massives. From the quaternary sediments, the deluvial slope deposits of solifluction origin prevail. They represent a rather heterogeneous set of substrates with various thicknesses of the block deposits. Peat is abundant and sediments of glacial origin are scarce.

The Bohemian Forest belongs to the oldest mountains in central Europe with large-scale relicts of plateau above 1000-1100 m altitude. In comparison with other mountains in the Czech Republic, it has a more moderate climate and a high mean altitude, only exceptionally lower than $600 \mathrm{~m}$. The highest peaks on the Bavarian side reach over $1400 \mathrm{~m}$. Annual precipitation varies between 1000 (Kvilda, $1058 \mathrm{~m}$ about sea level) and $1300 \mathrm{~mm}$ (Prášily, $850 \mathrm{~m}$ a.s.l.) in our study area. The mean annual temperature ranges from 4.2 (Churáňov, $1122 \mathrm{~m}$ a.s.l.) to $5.9{ }^{\circ} \mathrm{C}$ (Kašperské Hory, $780 \mathrm{~m}$ a.s.1.). Podsols prevail at higher altitudes; spodo-dystric cambisols are also common, while rankers and histosols or lithosols are more rare (see Zelenková et al., 2000).

\subsection{Data sampling}

Sofron (1981) recorded most phytocoenological relevés in 1972, a few in 1970 and 1976. These relevés were used as a basis for the evaluation of the spruce forest changes. The localities of these recorded relevés, which could be properly identified, were repeatedly 


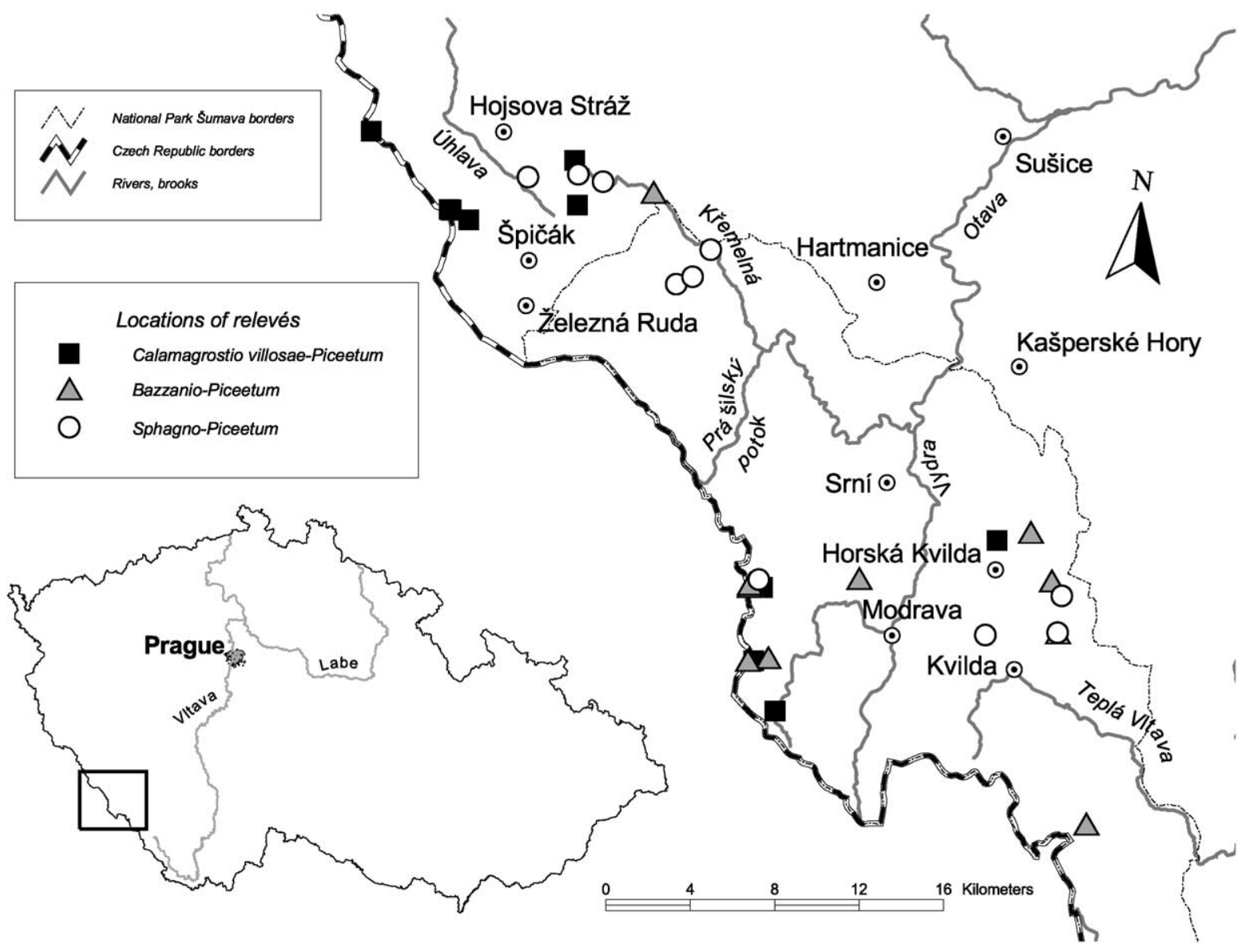

Fig. 1. Location of the resampled relevés in Natural Park Šumava and nearby surroundings.

recorded in 1999 by Neuhäuslová and Sofron. In order to be consistent with the methodology to these workers, an $11^{\circ}$ dominance-abundance scale by Domin (Domin ex Krajina, 1933a,b) was also used to record the new relevés. For further evaluation, this scale was then converted to the (Braun-Blanquet, 1964) scale by means of a table by Dahl and Hadač (1941). A total of 28 relevés were repeatedly recorded -9 in Calamagrostio villosae-Piceetum (incl. Vaccinio myrtilliPiceetum and Deschampsio-Piceetum sensu Sofron, 1981), 10 in Bazzanio-Piceetum (=MastigobryoPiceetum), and 9 in Sphagno-Piceetum. Areas where the forests were replaced by substitute clearing communities, or spruce stands with dead trees were not recorded. The position of the releve centre was localised by GPS with sub-meter horizontal accuracy. The age of the analysed stands was over 100 (120) years.
The sites of the following relevés by Sofron (1981) were chosen for repeated recording:

- Calamagrostio villosae-Piceetum (incl. Deschampsio flexuosae-Piceetum and Vaccinio myrtilliPiceetum sensu Sofron, 1981): 7, 8, 18, 20, 24 in Table 1, pp. 32-33, rel. 31 in Table 2, p. 43, rel. 32, 34, 36 in Table 3, pp. 46-47:

- Bazzanio-Piceetum: rel. 47, 48, 49, 54, 63, 67, 68, 69, 76, 77 in Table 5, pp. 62-65, and

- Sphagno-Piceetum: rel. 82, 83, 85, 87, 88, 91, 97, 98, 106 in Table 6, pp. 70-73.

Stands classified as belonging to Calamagrostio villosae-Piceetum are mostly under management. However, we did not suppose any strong intervention (cutting, planting) in the last 30 years, with the exception of one stand (Jezerní Mountain) with sporadic new 
plantation. (With respect to the small number of samples, we decided to also include this debatable sample.) Our assumption is based on the characteristics of the analysed stands and the knowledge that forest management activities are mostly oriented to younger stands. The other stands classified into the remaining two syntaxa can be taken as natural, without any activities related to forest plantation. The area of resampled relevés was the same as that of the corresponding original relevés $\left(100-400 \mathrm{~m}^{2}\right)$.

\subsection{Data analysis}

Time changes in the particular spruce communities and species turnover were tested by redundancy analysis (RDA, covariance matrix - option "Centre and Standardise" in CANOCO for Windows program). The (Braun-Blanquet, 1964) cover scale was converted into corresponding values, e.g. 1 into 1,2 into 2 and small values were converted as follows: $r=0.1 ;+=0.5$. For a detailed description of the problems related to cover data transformation, see van der Maarel (1979). The use of linear ordination methods was supported by the length of gradient in DCA analysis (less than 3 S.D. units for all three data sets). The cover values of all three vegetation layers were analysed together. The sets of sample plots for the individual communities were analysed separately. All sample plots and all species were active in the analysis. We did not down-weigh the species with low frequency but for the interpretation of changes only species with occurrence in more than three relevés were used.

The age of the relevés was treated as an environmental variable and each pair of relevés (i.e. sample plots) as covariables. Permutations were conditioned by covariables. Changes in abundance and species composition were assessed from the species scores on the first axis. The ordination was performed by CANOCO for Windows package (Ter Braak and Šmilauer, 1998).

The presence of successional trends according to ordination axes was tested by comparing sample scores between the years. Detrended correspondence analysis (DCA) was used in this case and the samples from all three communities were analysed together. The comparison of the scores was done by non-parametric Wilcoxon's paired signed-rank test (Zar, 1999). Species diversity was calculated from the species cover as a Shannon-Wiener index (Begon et al., 1990). The original Braun-Blanquet scale values were transformed as follows: $r=0.1,+=1,1=2.5$, $2=15,3=37.5,4=62.5,5=87.5$.

Main environmental factors were estimated indirectly using Ellenberg's indicator values (Ellenberg et al., 1992) for light, temperature, moisture, soil reaction and nitrogen. Data for nitrogen were available for higher plants only. Mean values were calculated for each relevé using the Braun-Blanquet scale after transformation to 1-7. To test the shift of ecological factors, mean sample indicator values for each relevé were compared between the years. With the aim to visualise the changes of environmental factors, species indicator values were correlated with species scores on the first RDA axis, which represents the time scale.

Differences between cover of the vegetation layers, as well as those of species number and species diversity, were also analysed by non-parametric Wilcoxon's paired signed-rank test. The Braun-Blanquet cover values were similarly converted to calculate diversity indices and summed over all species in particular layers.

Data processing was carried out with the SPSS program, version 10.0.5 (SPSS, 2000).

\section{Characteristics of the analysed spruce communities}

\subsection{Calamagrostio villosae-Piceetum Hartmann in Hartmann and Jahn (1967)}

This syntaxon (incl. Deschampsio flexuosae-Piceetum Hadač et al., 1969; Oxalido-Piceetum Krajina, 1933a,b; Březina et Hadač in Hadač et al., 1969; Vaccinio myrtilli-Piceetum, Szafer et al., 1923; Sofron, 1981) is the most frequent in the area studied. It includes stands with dominant spruce, at present almost the only tree- and shrub-layer species in prevailing plantations. In near-natural stands, Sorbus aucuparia, Fagus sylvatica or Abies alba occur. However, their occurrence is very rare in the central part of the Šmava National Park, due to forest management and high number of deer. Calamagrostis villosa, Avenella flexuosa, Luzula sylvatica or Vaccinium myrtillus dominate the species-poor field layer. Dryopteris dilatata, Oxalis acetosella and Trientalis europaea occur 
frequently, but with low abundance. The ground layer is usually rich in species; most common are Dicranum scoparium, Polytrichum formosum and Sphagnum girgensohnii, sometimes Rhytidiadelphus loreus (cf. also Jirásek, 1996; Jirásek in Husová et al., 2002).

\subsection{Bazzanio-Piceetum Br-Bl. and Sissingh in Braun-Blanquet et al. (1939)}

Edaphically and microclimatically influenced waterlogged spruce forests poor in higher plants but with a species-rich ground layer, occur at montane and submontane levels. The canopy is usually formed by spruce only. Here and there, Betula pubescens (incl. Betula carpatica), Pinus sylvestris or $P$. rotundata, and rarely regenerating beech are admixed. The field layer is dominated by several more-or-less constant species (V. myrtillus, Vaccinium vitis-idaea, A. flexuosa, $C$. villosa, D. dilatata). In the ground layer, dominated by Bazzania trilobata (rarely S. girgensohnii) frequently covering large areas, more than 20 bryophytes were often recorded. The diagnostic species $B$. trilobata also occurs in another spruce forests syntaxa, however, with much lower abundance.

\subsection{Sphagno-Piceetum (R. Tüxen 1937) (Hartmann, 1953)}

Open, stunted stands (cover 50-60\%), often with insufficient differentiation of tree and shrub layers, are found in the marginal zone of the peatlands. Dominant spruce with an occasional admixture of $P$. sylvestris, $P$. rotundata and/or B. pubescens s.l., poorly developed field layer containing the most common V. myrtillus, $V$. vitis-idaea, Eriophorum vaginatum and Oxycoccus palustris, and dense cover of the ground layer with prevailing Sphagnum species are typical. Vaccinium uliginosum, Carex rostrata or Equisetum sylvaticum occur rarely, but with high dominance in spots. From the bryophytes, Sphagnum recurvum s.l. and Polytrichum commune prevail. Sometimes, Sphagnum magellanicum, Sphagnum russowii, S. cuspidatum or S. riparium occur with high dominance. In the individual stands, the spruce trees are of different age ([50] 80-150 years); the sub-layer trees are often dead. This unit occupies the most extreme sites where the spruce is limited in its growth by excessive waterlogging on the old bogs of different thicknesses.

\section{Results}

\subsection{Species composition}

Resampling of spruce forests recorded in the 1970s (Sofron, 1981) in the Bohemian Forest showed high variation in species cover and frequency, reflecting high site heterogeneity in the three communities analysed. The heterogeneity between plots (treated as covariables) explained always more than $50 \%$ variability in data set (Table 1). After removing the plot effect (using permutation by blocks defined by plots), the RDA revealed significant time changes in species composition (Table 1) in climatic and Bazzania-rich spruce stands. The changes in waterlogged stands of the Sphagno-Piceetum are close to the level of significance 5\% $(P=0.06)$. The response of individual species to time, treated as an environmental variable, indicates scores on the first canonical axis (see Appendix A). The cover or abundance of species with negative scores decreased in time and vice versa. The changes in cover and abundance of individual species are discussed in the next section.

The difference in species composition between communities and its shift during the analysed period was visualised in DCA ordination space (Fig. 3). The samples are clearly differentiated to three communities according to the first axis, which could be explained by moisture gradient. The observed pattern according to the second axis cannot be explained by a single factor.

Table 1

Characteristics of RDA analysis for three different forest communities $^{\mathrm{a}}$

\begin{tabular}{lllll}
\hline Community & $\begin{array}{l}\text { Covariables } \\
\text { variability }\end{array}$ & $\begin{array}{l}\text { First axis } \\
\text { variability }\end{array}$ & $F$ & $P$ \\
\hline $\begin{array}{c}\text { Calamagrostio- } \\
\quad \text { Piceetum }\end{array}$ & 56.5 & 16.9 & 1.629 & 0.009 \\
$\begin{array}{c}\text { Bazzanio-Piceetum } \\
\text { Sphagno-Piceetum }\end{array}$ & 51.3 & 17.5 & 1.915 & 0.004 \\
\hline
\end{tabular}

${ }^{a}$ Covariables variability indicates the percentage of variability explained by the heterogeneity between locations. (The sample plots were treated as covariables.) First axis variability indicates percentage variability explained by first canonical RDA axis after fitting covariables. Time was treated as a single environmental factor. Significance was estimated using the Monte Carlo permutation test. 
The analysis of shift in sample position in ordination space over all communities did not reveal any general successional trend in species composition according to the gradients described by the two DCA axes. The pairwise comparison of sample scores of original and new relevés on the first and second DCA axes, respectively, between the two samplings (T2-T1) was not significant for any community compared.

\subsection{Cover and frequency of particular species}

\subsubsection{Calamagrostio villosae-Piceetum}

The decrease in both cover and frequency of the hygrophilous species or species of dense canopy Athyrium distentifolium and $O$. acetosella, and the higher dominance and increase in frequency of spruce (shrub and field layer) is remarkable providing evidence of good regeneration. Notable is that the relatively frequent occurrence of Galium saxatile missing in the 1970s and providing evidence of its invasion beginning on the suitable forest sites in the area of the Bohemian Forest. A somewhat higher proportion of $D$. dilatata and $L$. sylvatica in the stands was also recorded compared with the 1970s. From the bryophytes, only a higher proportion of $D$. scoparium and S. girgensohnii was observed.

\subsubsection{Bazzanio-Piceetum}

An increase in dominance and frequency can be seen in many acidophilous species, typical of central European spruce or spruce-beech forests of the submontane to supramontane levels (partly occurring in subalpine grasslands, too). Of these species, Picea abies (both shrub and field layers), S. aucuparia, A. flexuosa and $D$. dilatata (field layer) must be mentioned, as well as V. vitis-idaea and Lycopodium annotinum, where the increase in frequency is less marked. Also, a number of spruce-forest species such as $C$. villosa (at present occurring very frequently in clearings of the highest altitudes) and Homogyne alpina increased. Bryophyte species of waterlogged spruce forests and peatlands (Sphagnum species, e.g. $S$. girgensohnii, S. magellanicum) as well as D. scoparium, Ptilidium ciliare, B. trilobata and Dicranodontium denudatum increased in abundance. On the other hand, the frequency of some bryophytes (Sphagnum capillifolium, Cephalozia lunulifolia) decreased.

\subsubsection{Sphagno-Piceetum}

Differences in this community concern mainly higher abundances of A. flexuosa, V. vitis-idaea, $T$. europaea, C. villosa, and V. uliginosum in the field layer, as well as more frequent occurrence and cover of $P$. abies in the shrub layer and B. pubescens agg. in the tree layer (Appendix A). On the other hand the decrease in Deschampsia caespitosa and that in cover of hygrophilous Sphagnum species (Sphagnum fallax, $S$. russowii) must be mentioned.

\subsection{Species richness and diversity}

The analysis of number of species per plot calculated over all communities (Fig. 2) and in detail for each community and vegetation layer (Table 2) showed a striking shift to more species-rich communities. Species numbers calculated over all vegetation layers were significantly higher in 1999 in all three communities (Table 3). Consequently, vegetation diversity in all three communities also increased significantly with species richness (Table 4). Comparison of particular vegetation layers revealed a significant increase in species numbers only in the field layer in Sphagno-Piceetum and in the ground layer in the two waterlogged spruce forests.

\subsection{Layer cover}

Opening of spruce canopies indicated by a significant decrease of tree-layer cover was found only in

Table 2

The total number and number of retreated or emerged species during time, counted over all relevés within particular communities (species occurring in two or more relevés only are included)

\begin{tabular}{|c|c|c|c|c|}
\hline \multirow[t]{2}{*}{ Community } & \multicolumn{2}{|c|}{ Total no. of species } & \multicolumn{2}{|c|}{ No. of species } \\
\hline & $1970 \mathrm{~s}$ & 1999 & Retreated & Emerged \\
\hline \multicolumn{5}{|c|}{ Calamagrostio-Piceetum } \\
\hline Field layer & 16 & 20 & 2 & 6 \\
\hline Ground layer & 13 & 17 & 4 & 8 \\
\hline \multicolumn{5}{|c|}{ Bazzanio-Piceetum } \\
\hline Field layer & 14 & 16 & 3 & 5 \\
\hline Ground layer & 27 & 30 & 9 & 12 \\
\hline \multicolumn{5}{|c|}{ Sphagno-Piceetum } \\
\hline Field layer & 35 & 49 & 8 & 22 \\
\hline Ground layer & 20 & 30 & 6 & 16 \\
\hline
\end{tabular}




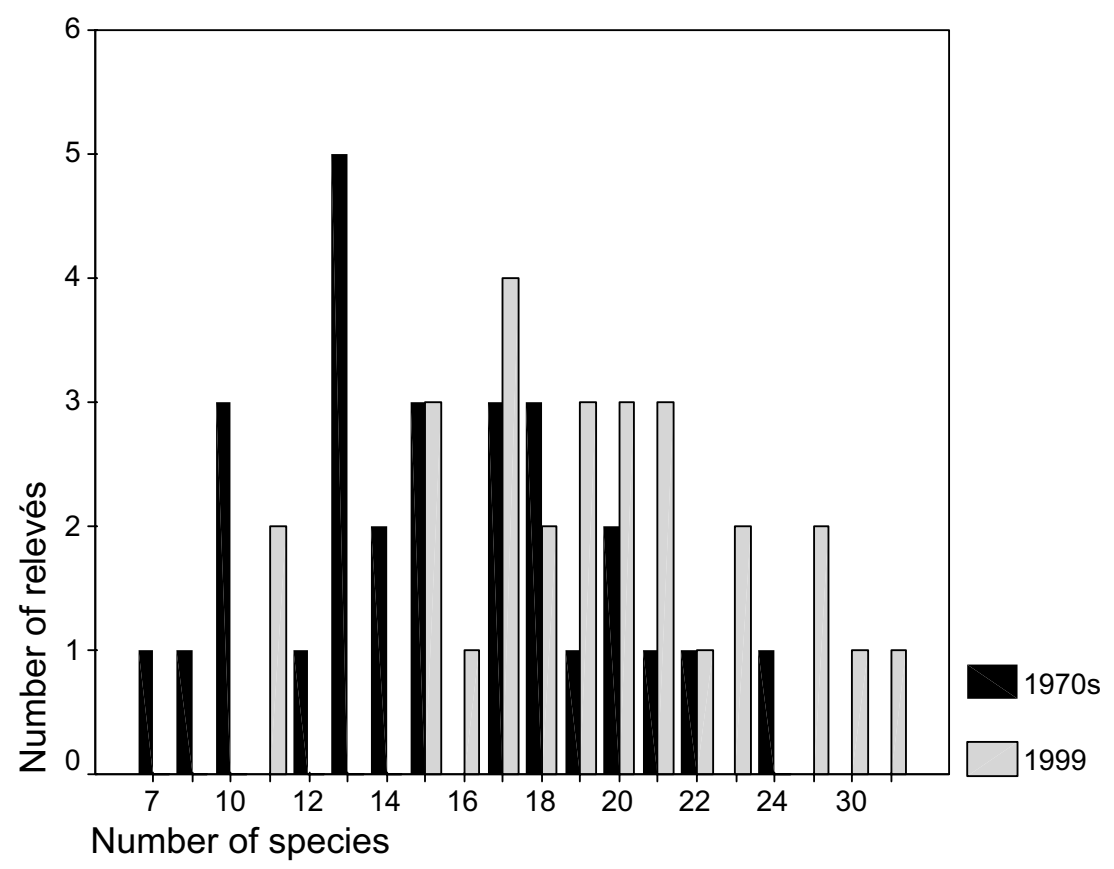

Fig. 2. Time changes in the distribution of number of species per plot over all communities $(P<0.01$, Mann-Whitney test, $n=58)$.

climatic spruce stands (Calamagrostio villosae-Piceetum) (see Table 5). The mean cover of the tree layer calculated as a sum of cover of particular species decreased from $61.56 \pm 7.84$ to $45.33 \pm 16.56 \%$, but on the other hand, the mean cover of the shrub layer increased from $0.67 \pm 1.32$ to $4.78 \pm 5.40 \%$. The cover of tree- and shrub layers in other two forest communities was stable except of an increase of the

Table 3

Changes in species number per sample plot ${ }^{\mathrm{a}}$

\begin{tabular}{|c|c|c|c|c|c|c|}
\hline \multirow[t]{2}{*}{ Community } & \multicolumn{2}{|c|}{ Mean no. of species } & \multicolumn{2}{|c|}{ No. of ranks 1970 s-1999 } & \multirow[t]{2}{*}{$Z$} & \multirow[t]{2}{*}{$P$} \\
\hline & 1970s & 1999 & Negative & Positive & & \\
\hline \multicolumn{7}{|c|}{ Calamagrostio-Piceetum } \\
\hline Field layer & 8.67 & 9.56 & 6 & 2 & -1.354 & n.s. \\
\hline Ground layer & 3.67 & 4.78 & 4 & 3 & -1.364 & n.s. \\
\hline All layers & 14.00 & 16.44 & 7 & 1 & -2.263 & 0.024 \\
\hline \multicolumn{7}{|c|}{ Bazzanio-Piceetum } \\
\hline Field layer & 5.40 & 6.80 & 7 & 3 & -1.698 & n.s. \\
\hline Ground layer & 7.20 & 9.80 & 8 & 1 & -2.561 & 0.010 \\
\hline All layers & 14.10 & 18.50 & 10 & 0 & -2.809 & 0.005 \\
\hline \multicolumn{7}{|c|}{ Sphagno-Piceetum } \\
\hline Field layer & 10.89 & 15.22 & 6 & 3 & -1.899 & 0.058 \\
\hline Ground layer & 4.78 & 7.22 & 7 & 1 & -2.040 & 0.041 \\
\hline All layers & 17.78 & 25.11 & 7 & 1 & -2.316 & 0.021 \\
\hline
\end{tabular}

${ }^{\mathrm{a}} Z$ statistics and significance probability $(P)$ refers to two-tailed Wilcoxon signed-rank test. All significant results indicate increase of species number. Tree and shrub layer were not analysed separately due to small number of species, but they were included in the "all layers" category. n.s. $=P>0.05$. 
Table 4

Differences in diversity calculated as Shannon-Wiener index $H^{\prime}$ between original and new records ${ }^{\mathrm{a}}$

\begin{tabular}{|c|c|c|c|c|c|c|}
\hline \multirow[t]{2}{*}{ Community } & \multicolumn{2}{|c|}{ Mean $H^{\prime}$} & \multicolumn{2}{|c|}{ No. of ranks $1970 s-1999$} & \multirow[t]{2}{*}{$Z$} & \multirow[t]{2}{*}{$P$} \\
\hline & $1970 \mathrm{~s}$ & 1999 & Negative & Positive & & \\
\hline Calamagrostio-Piceetum & 0.392 & 0.649 & 9 & 0 & -2.666 & 0.008 \\
\hline Bazzanio-Piceetum & 0.613 & 0.786 & 8 & 2 & -2.191 & 0.028 \\
\hline Sphagno-Piceetum & 0.515 & 0.827 & 8 & 1 & -2.547 & 0.011 \\
\hline
\end{tabular}

${ }^{\text {a }} Z$ statistics and significance probability $(P)$ refers to two-tailed Wilcoxon signed-rank test. All results indicate increase of diversity.

Table 5

Changes in vegetation cover of all layers calculated as the sum of cover of particular species ${ }^{\mathrm{a}}$

\begin{tabular}{|c|c|c|c|c|c|c|}
\hline \multirow[t]{2}{*}{ Community } & \multicolumn{2}{|c|}{ Mean cover } & \multicolumn{2}{|c|}{ No. of ranks 1970s-1999 } & \multirow[t]{2}{*}{$Z$} & \multirow[t]{2}{*}{$P$} \\
\hline & 1970 s & 1999 & Negative & Positive & & \\
\hline \multicolumn{7}{|c|}{ Calamagrostio-Piceetum } \\
\hline Tree layer & 61.56 & 45.33 & 1 & 7 & -2.035 & $0.042^{\mathrm{b}}$ \\
\hline Shrub layer & 0.67 & 4.78 & 6 & 0 & -2.264 & $0.024^{\mathrm{c}}$ \\
\hline Field layer & 103.22 & 106.56 & 3 & 6 & -0.059 & n.s. \\
\hline Ground layer & 9.89 & 26.00 & 7 & 2 & -2.073 & $0.038^{\mathrm{c}}$ \\
\hline \multicolumn{7}{|c|}{ Bazzanio-Piceetum } \\
\hline Tree layer & 70.80 & 54.60 & 1 & 6 & -1.362 & n.s. \\
\hline Shrub layer & 1.20 & 3.00 & 5 & 2 & -1.052 & n.s. \\
\hline Field layer & 12.60 & 46.20 & 10 & 0 & -2.805 & $0.005^{\mathrm{c}}$ \\
\hline Ground layer & 38.60 & 76.30 & 9 & 1 & -2.601 & $0.009^{\mathrm{c}}$ \\
\hline \multicolumn{7}{|c|}{ Sphagno-Piceetum } \\
\hline Tree layer & 30.89 & 33.22 & 4 & 1 & -0.677 & n.s. \\
\hline Shrub layer & 4.89 & 14.11 & 5 & 0 & -2.032 & $0.042^{\mathrm{c}}$ \\
\hline Field layer & 62.67 & 88.89 & 7 & 2 & -2.192 & $0.028^{\mathrm{c}}$ \\
\hline Ground layer & 83.33 & 66.89 & 4 & 5 & -0.770 & n.s. \\
\hline
\end{tabular}

${ }^{\mathrm{a}} Z$ statistics and significance probability $(P)$ refers to two-tailed Wilcoxon signed-rank test, n.s. $=P>0.05$.

${ }^{\mathrm{b}}$ Indicates decrease of cover.

${ }^{\mathrm{c}}$ Indicates increase during analysed period.

shrub-layer cover of the Sphagno-Piceetum from $4.89 \pm 4.70$ to $14.11 \pm 11.05 \%$.

Cover increase in either field- or ground layer was found in all three communities (Table 5). The Bazzanio-Piceetum showed the most marked changes, its field-layer cover increased from $12.60 \pm 6.29$ to $46.20 \pm 15.46$ and its ground layer from $38.60 \pm$ 25.18 to $76.30 \pm 13.17$.

\subsection{Indirectly estimated ecological factors}

Comparison of environmental conditions between the original and new records have been done for five factors (see methods) and two (field and ground) vegetation layers. Significant shift of environmental factors based on mean sample of Ellenberg's values was found only for light (towards heliophilous species of field layer in Calamagrostio-Piceetum) and for soil acidity (towards more acidic soils at species of ground layer in Sphagno-Piceetum). To visualise the general shift of environmental factors, we plotted species indicator values against the species scores on the first RDA axis. However we have not found any correlation between species scores and species indicator values for any community. The results are not displayed with respect to a long list of analyses and only two significant results. 


\section{Discussion}

\subsection{Problems with relevés resampling and changes evaluation}

Several problems, which may strongly influence the results of further analyses and interpretation of results, must be solved in studies dealing with relevés sampled repeatedly over time: (i) inaccurate position of resampled relevés with respect to the position of original relevés; (ii) different interpretation of the degree of cover by different investigations (including use of different scales); (iii) overlooking of species, etc.

Thus, according to Malmer et al. (1978), every study on permanent plots repeated after $30-50$ years will be subject to criticism that the data are not fully comparable because no person can repeat any investigation without mistakes after such a long period.

Some inadequacies can be partly removed. For example, inaccurate position can be addressed by making several records in the neighbourhood of the approximately localised old relevé, which include most of the non-homogeneity of a given stand. However this approach could seriously complicate interpretation of the results. Different values can be transferred by some, not exactly precise way to one scale (see van der Maarel, 1979). Other factors, e.g. the different subjective estimation of abundance and cover, or overlooking of species by different authors cannot be quantified but do not cause systematic bias in ordination analysis as it is quite insensitive to sampling errors (Lepš and Hadincová, 1992).

As mentioned above, we cooperated with the author of the original relevés, J. Sofron, during the repeated recording. Thus, we largely eliminated problems with the cover grades used and their interpretation. We also decided to rely on Sofron's localisation, and on the site of the original relevé we took only one record (a procedure usually used in evaluation of permanent plots). We are aware of the danger of misinterpretation. The variability interpreted as time changes could also include (mostly due to inaccurate localisation) spatial heterogeneity of vegetation. However, we believe that cooperation with the author of original relevés was sufficient to diminish the risk of an uncertain location of the individual relevés. Nevertheless, all observed changes should be evaluated with respect to the above-mentioned sampling problems.

\subsection{Vegetation changes}

Direct gradient analysis (RDA) confirms changes in species composition after about 30 years; however, displacement of plots along both DCA axes seems to be chaotic (Fig. 3) and does not indicate any general trend.

On the other hand, changes in frequency and cover of particular species and changes in species richness and diversity are remarkable and can indicate a shift of environmental conditions.

Only two main cumulative factors are displayed in two-dimension space of the DCA ordination diagram, other factors can be hidden there. Unfortunately, no direct measurement of environmental characteristics has been done within sampling of the original relevés. Therefore, only indirect estimation of ecological factors using Ellenberg's values was performed. Many comparisons between the two records have been done based on mean sample value for different factors and different vegetation layers. Only two comparisons yielded significant differences and indicated an increase in light penetration into climax spruce forests and increased acidity of Sphagnum-rich spruce forest. No other shifts of environmental conditions were confirmed by these analyses. Indirect measurement of environmental factors must be considered while interpreting these results. In practice, the indicator values of Ellenberg's implicitly defined scale seem to work well, but this type of environmental calibration does not include the interaction effect of other factors (Ter Braak and Gremmen, 1987) and could significantly differ from real site conditions. For example, for Vaccinio-Piceetea, Wamelink et al. (2002) found a negative relationship between Ellenberg's $R$ values and soil acidity while a positive relationship was expected. Comparison of individual species response and mean sample indicator values can therefore yield inconsistent results.

From a statistical point of view, we have also to be aware of a low power of all performed tests due to low number of samples.

Based on the analysis of indicator values, changes in light conditions seem to be the most important factor observed in climax spruce forests. This hypothesis is also supported by a significant decrease in treelayer cover in these stands which can be attributed to 


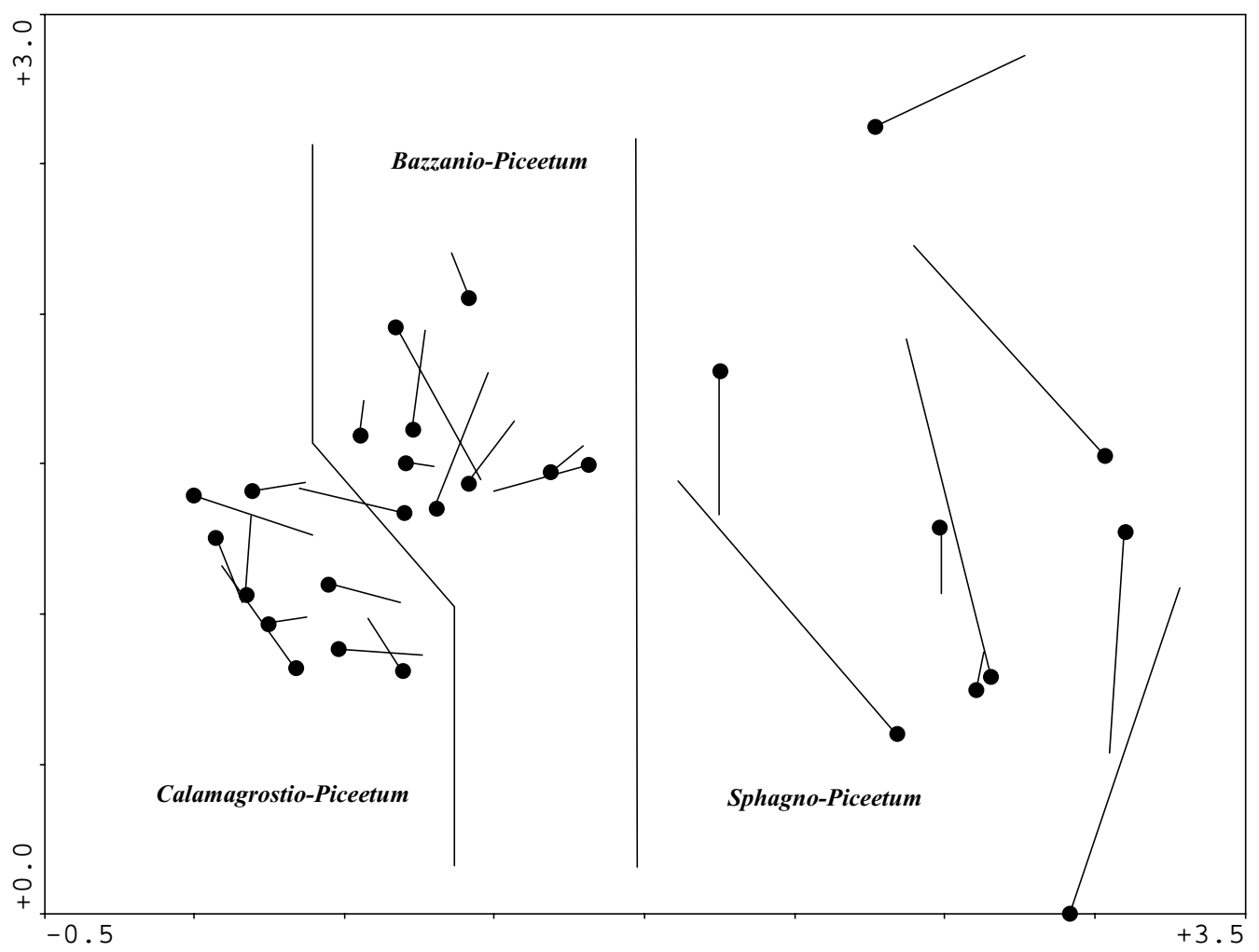

Fig. 3. Shifts in plot position in ordination space (DCA) from 1970s to 1999. Position of relevés from 1970s is indicated by dots; lines show replacement during analysed period.

wind and snow disturbances in the last few decades (Sofron, 2000, ms.), to the aftermath of bark-beetle attack and rapidly progressing defoliation since 1992 (see Zelenková et al., 2000). Changes in particular species cover and frequency indicate improved light conditions and decline of hygrophilous and sciophilous species like $O$. acetosella, and increased cover and frequency of $D$. dilatata, a species of open stony slopes at lower altitudes of the spruce-forest belt in the Bohemian Forest. Similar to the Krkonoše Mountains (Vacek et al., 1999), dominant species of the field layer (C. villosa, A. flexuosa, V. myrtillus) increase their cover with the loss of canopy foliage in the Bohemian Forest. However, in the Krkonoše Mountains, the canopy changes were caused directly by pollution stress. Nygaard and Ødegaard (1999) considered the changes in canopy and consequent changes in light availability as the most important ecological factor causing long-term changes in south boreal coniferous forests. However, no changes in light indicator values and/or in tree-layer cover were observed in the two waterlogged spruce forests of the Bohemian Forest. Changes in Ellenberg's mean sample values indicated only increased soil acidity but this conclusion was drawn from analysis of ground layer species - mainly bryophytes - which possess a lower predicative value with respect to Ellenberg's values than vascular plants (cf. Düll in Ellenberg et al., 1992).

Further explanation can be derived from the dynamics of individual species. The RDA analysis (Appendix A) presents good information on increasing or decreasing species abundance or cover during the analysed period. For example, higher frequency of A. flexuosa, higher dominance and/or frequency of $C$. villosa and V. vitis-idaea in waterlogged spruce forests, as well as the frequent regeneration of $S$. аисиparia in the Bazzanio-Piceetum give evidence of decreasing soil moisture. The opening of spruce canopies indicated by a decrease of tree-layer cover was 
not confirmed. Also, the newly occurring species in the Sphagno-Piceetum, also partly in the BazzanioPiceetum, indicate the tendency towards drier sites: from the meadow species - Anthoxanthum odoratum, Calluna vulgaris, Festuca rubra, Luzula multiflora, Dactylorhiza fuchsii, from the forest species $-S$. aucuparia, Soldanella montana, B. carpatica, Hieracium lachenalii.

A higher dominance of E. vaginatum and Oxyccocus palustris in waterlogged spruce forests of the Bohemian Forest does not contradict the hypothesis on soil moisture reduction - it is evidence to more suitable moisture conditions in former strongly waterlogged stands of the Sphagno-Piceetum with reduction of excessive soil moisture in the last 30 years and a certain retreat of $C$. rostrata.

The only general trend found - a significant shift to species-rich communities and to higher diversity - was observed in all communities studied. The most remarkable and striking shift was found in the Sphagno-Piceetum. These results are in contradiction with other authors who, recorded species-poor types. These authors explained the decrease of species richness, for example, by pollution stress (Vacek et al., 1999 ) or by increased canopy cover (Nygaard and Ødegaard, 1999). However these factors are either of low importance (pollution stress) or were even excluded (canopy increase) in our study plots. Some small changes can be explained by short-term variability (cf. Økland, 1995; Økland and Eilertsen, 1996). Changes is bryophytes and lichens can be partly attributed to wrong determination by some authors (especially Sphagnum or Calypogeia species), overlooking (Pohlia and Cephalozia species), and/or local disturbances (e.g. Mylia anomala, Dicranella heteromalla). However, such a marked increase in species number as in the Sphagno-Piceetum, especially in higher plants (14 species more in total and 4.33 more per relevé in average) cannot be explained by any of the above-mentioned factors.

The increasing number of vascular plants can be linked to chemical changes in the atmosphere during the last $\approx 10-15$ years. First atmospheric acidification records in the Bohemian-Forest lakes date between 1959 and 1961, with the heaviest impact culminated around 1980 (Vrba et al., 2000), which corresponded with the time of collection of the first lot of relevés. During the last 15-10 years, the amount of sulphur dioxide in wet depositions dropped markedly as well as the content in Bohemian-Forest lakes (Veselý, 1996). Also, Kopáček et al. (2001) mentioned a fall in atmospheric acidification of the Bohemian-Forest lakes from the second half of the 1980s. Thus, $\mathrm{pH}$ of the Bohemian-Forest lakes rose since the 1980s, e.g. in the Bavarian lakes (Kleiner Arbersee, Rachelsee) it increased from 4.3 in 1983 to 4.8 in 1999 (Schaumberg, 2000). This trend probably influenced the increase in both abundance and diversity of algae and other phytoplankton in some lakes. Mánek (1998) also mentioned the dependence of species diversity of riverside vascular plants on the chemistry of Bohemian-Forest waters. Lower pollution stress in Bohemian Forest compared with other mountains was also observed by Sucharová and Suchara (2001).

This explanation is in contradiction with the predicted increase of acidity in waterlogged forests. However, this finding is based on debatable and indirect measurement only (see above) and was significant for one community and one species group (bryophytes) only. It cannot compete with proof of decreasing acidity from direct measurement of pollutant contents by several authors. Rather it suggests the doubtful use of Ellenberg's values than on conflicting trends in acidity.

Climate warming is an alternative explanation of species richness increase and shift to drier types. We can observe frequent attempts to shift forest vegetation belts to higher altitudes (e.g. Brzeziecki et al., 1995; Majer, 2001; Neuhäuslová, 2001; Vacek and Mayová, 2000; Vinš et al., 1996; Buček and Kopecká, 2001, etc.). As a result of global warming, the retreat of spruce forests from the Šumava National Park and their replacement by mountain spruce-beech forests is to be expected in the near future, around the year 2010, according to Vinš et al. (1996) and Buček and Kopecká (2001). This prediction, together with prediction of soil moisture decrease, could be supported by the comparison of waterlogged spruce forest area on the Geobotanical Map of the Czech Republic compiled at the beginning of the second half of the last century (Mikyška, 1968-1972) with the Map of Potential Natural Vegetation of the Bohemian Forest (Neuhäuslová et al., 2002). It is unrealistic to suppose that the remarkable reduction of the spruce forest area on the Map of Potential Natural Vegetation of the Šumava National Park was due to concept differences 
in mapping units between the different authors of the same mapping school.

Differences in climatic data measured during several decades and more frequent dry periods also show certain shifts to a warmer climate (cf., e.g. Staněk (2002) or data from the climatic stations at Březník, etc. depon. in: Administration of the National Park and Protected Landscape Area, Bohemian Forest).

Fragmentation of forests resulting from bark-beetle attacks and subsequent forest clearcut must also be considered as one of the possible sources of increasing species richness. Many new clearings can serve as a source of species, which can invade drying stands in waterlogged spruce forests.

None of the hypotheses discussed in relation to waterlogged forests (decrease of atmospheric acidification, global warming or forest fragmentation) is in contradiction with observed species changes in climax spruce forest. However, since all these hypotheses cannot be confirmed by our data we suggest that the main factor responsible for changes observed in climax spruce forest is a pronounced decrease of canopy cover.

It is necessary to mention specific cases when species changes cannot be related to changes in the stands analysed. For example, the recent invasive species G. saxatile points to its current spreading on suitable, more-or-less open fresh to moist sites on mountain clearings and in open forests in Bohemian Forest since the first half of the 20th century (cf. Slavík, 2000: 150). The decline of chionophilous species $A$. distentifolium in the living forest on the northern side of the Jezerní Mountain is hard to explain, because this species has been growing there on extensive clearing at a distance of ca. $0.5 \mathrm{~km}$ to the NW with high dominance and vitality. A similar, fairly hardly explicable phenomenon was mentioned by Petermann and Seibert (1979) from the neighbouring Bavarian Forest, National Park Germany, and by Krahulec (in litt.) from the Hrubý Jeseník Mountains. It was not possible to prove if the cause was due to a change in local snow conditions or other factors.

\section{Conclusion}

The dynamics of coniferous stands in the Bohemian Forest have been studied based on repeated sampling of 28 forest stands classified to three communities (climax spruce forests - Calamagrostio-Piceetum and waterlogged spruce forests - Bazzanio-Piceetum and Sphagno-Piceetum). Significant changes in species composition have been confirmed. However, ordination analysis over all plots did not detect any common trends in all the communities. Species turnover and changes in cover and frequency of particular species indicated a tendency towards communities of open and/or drier vegetation types. Also, the shift to more species-rich communities has been found in all the vegetation layers analysed (tree, shrub, field and ground). The most remarkable shift was detected in waterlogged stands. The single direct factor, decrease in canopy cover, together with more complex factors - decrease of air pollution, forest fragmentation or global warming - were discussed as possible explanations for the changes observed.

\section{Acknowledgements}

The authors thank the Grant Agency of the Czech Republic for financial support (grant project 206/96/ 1416). This study was also supported by the grant project AVOZ 6005908. Our thanks to B. Buryová and H. Franklová for determination of bryophytes and to V. Eltsova for data entry. P. Pyšek and M. Kovárová read and criticised the draft of this paper. Thanks are due to the both anonymous reviewers for many helpful comments on an earlier version of this contribution.

\section{Appendix A}

Species exchange survey. The first column gives species scores on the first axis of RDA analysis. The scores indicate correlation of species cover with time: cover of species with positive value increases and vice versa. The columns labelled by date give occurrence frequency in corresponding years. The last three columns refer to percentage number of plots where the species retreated, occurred in 1970s and persisted in 1999 and emerged, respectively. Percentage numbers are related to the total number of plots where the species occurred in either 1970s or 1999. Only species occurring in three or more relevés in any one of the time are included. Shrub and tree layers are marked 
with abbreviation: sl—shrub layer, tl—tree layer.

\begin{tabular}{|c|c|c|c|c|c|c|}
\hline Calamagrostio-Piceetum & First axis scores & $1970 \mathrm{~s}$ & 1999 & Retreated & Persisted & Emerged \\
\hline Picea abies & 0.615 & 7 & 9 & 0 & 100 & 22 \\
\hline Picea abies-s1 & 0.470 & 1 & 5 & 0 & 100 & 80 \\
\hline Galium saxatile & 0.427 & 0 & 3 & 0 & 0 & 100 \\
\hline Dicranum scoparium & 0.381 & 6 & 7 & 17 & 83 & 29 \\
\hline Dryopteris dilatata & 0.379 & 9 & 9 & 0 & 100 & 0 \\
\hline Sphagnum girgensohnii & 0.302 & 4 & 5 & 0 & 100 & 20 \\
\hline Luzula sylvatica & 0.282 & 6 & 6 & 0 & 100 & 0 \\
\hline Plagiothecium laetum & 0.267 & 1 & 3 & 0 & 100 & 67 \\
\hline Sorbus aucuparia-s1 & 0.260 & 1 & 3 & 0 & 100 & 67 \\
\hline Sorbus aucuparia & 0.255 & 6 & 6 & 33 & 67 & 33 \\
\hline Homogyne alpina & 0.228 & 4 & 6 & 25 & 75 & 50 \\
\hline Trientalis europaea & 0.216 & 4 & 6 & 25 & 75 & 50 \\
\hline Dicranodontium denudatum & 0.167 & 1 & 3 & 0 & 100 & 67 \\
\hline Vaccinium myrtillus & 0.160 & 5 & 7 & 0 & 100 & 29 \\
\hline Rhytidiadelphus loreus & 0.116 & 3 & 2 & 33 & 67 & 0 \\
\hline Barbilophozia lycopodioides & 0.093 & 4 & 4 & 25 & 75 & 25 \\
\hline Polytrichum formosum & 0.074 & 6 & 7 & 17 & 83 & 29 \\
\hline Avenella flexuosa & 0.058 & 9 & 9 & 0 & 100 & 0 \\
\hline Calamagrostis villosa & 0.000 & 8 & 9 & 0 & 100 & 11 \\
\hline Sorbus aucuparia-t1 & 0.000 & 3 & 2 & 67 & 33 & 50 \\
\hline Polytrichum commune & 0.000 & 2 & 1 & 50 & 50 & 0 \\
\hline Maianthemum bifolium & -0.098 & 5 & 3 & 40 & 60 & 0 \\
\hline Lycopodium annotinum & -0.149 & 2 & 1 & 50 & 50 & 0 \\
\hline Oxalis acetosella & -0.272 & 7 & 5 & 43 & 57 & 20 \\
\hline Athyrium distentifolium & -0.329 & 3 & 1 & 100 & 0 & 100 \\
\hline Picea abies- $\mathrm{t} 1$ & -0.557 & 9 & 9 & 0 & 100 & 0 \\
\hline Bazzanio-Piceetum & First axis scores & \multicolumn{2}{|c|}{ 1972/19741999 } & Retreated & Persisted & Emerged \\
\hline$\overline{\text { Picea abies }}$ & 0.706 & 9 & 10 & 0 & 100 & 10 \\
\hline Vaccinium myrtillus & 0.651 & 10 & 10 & 0 & 100 & 0 \\
\hline Dicranum scoparium & 0.582 & 8 & 10 & 0 & 100 & 20 \\
\hline Ptilidium ciliare & 0.500 & 0 & 4 & 0 & 0 & 100 \\
\hline Bazzania trilobata & 0.473 & 10 & 10 & 0 & 100 & 0 \\
\hline Dicranodontium denudatum & 0.446 & 5 & 9 & 0 & 100 & 44 \\
\hline Picea abies-s1 & 0.388 & 3 & 7 & 33 & 67 & 71 \\
\hline Vaccinium vitis-idaea & 0.383 & 4 & 5 & 0 & 100 & 20 \\
\hline Sorbus aucuparia & 0.376 & 4 & 7 & 25 & 75 & 57 \\
\hline Avenella flexuosa & 0.326 & 5 & 8 & 0 & 100 & 38 \\
\hline Lycopodium annotinum & 0.320 & 3 & 4 & 0 & 100 & 25 \\
\hline Dryopteris dilatata & 0.313 & 4 & 6 & 25 & 75 & 50 \\
\hline Sphagnum magellanicum & 0.288 & 3 & 5 & 0 & 100 & 40 \\
\hline Calamagrostis villosa & 0.278 & 8 & 7 & 25 & 75 & 14 \\
\hline Homogyne alpina & 0.226 & 1 & 2 & 0 & 100 & 50 \\
\hline Tetraphis pellucida & 0.218 & 2 & 4 & 0 & 100 & 50 \\
\hline Polytrichum formosum & 0.215 & 6 & 8 & 0 & 100 & 25 \\
\hline
\end{tabular}


Appendix A. (Continued)

\begin{tabular}{lcccrrr}
\hline Bazzanio-Piceetum & First axis scores & $1972 / 19741999$ & Retreated & Persisted & Emerged \\
\hline Sphagnum girgensohnii & 0.201 & 5 & 8 & 0 & 100 & 38 \\
Eriophorum vaginatum & 0.196 & 1 & 2 & 0 & 100 & 50 \\
Pleurozium schreberi & 0.169 & 1 & 3 & 100 & 0 & 100 \\
Polytrichum commune & 0.135 & 3 & 4 & 67 & 33 & 75 \\
Calypogeia integristipula & 0.113 & 2 & 2 & 100 & 0 & 100 \\
Sphagnum russowii & 0.038 & 3 & 4 & 33 & 67 & 50 \\
Anastrepta orcadensis & 0.000 & 2 & 1 & 50 & 50 & 0 \\
Lepidozia reptans & 0.000 & 2 & 2 & 50 & 50 & 50 \\
Rhytidiadelphus loreus & 0.000 & 2 & 2 & 50 & 50 & 50 \\
Dicranum fuscescens & -0.109 & 2 & 3 & 50 & 50 & 67 \\
Cephalozia lunulifolia & -0.316 & 3 & 0 & 100 & 0 & 0 \\
Sphagnum capillifolium & -0.344 & 3 & 1 & 67 & 33 & 0 \\
Picea abies-t1 & -0.380 & 10 & 10 & 0 & 100 & 0
\end{tabular}

\begin{tabular}{|c|c|c|c|c|c|c|}
\hline Sphagno-Piceetum & First axis scores & 197 & 1999 & Retreated & Persisted & Emerged \\
\hline Picea abies-s1 & 0.5835 & 7 & 9 & 0 & 100 & 22 \\
\hline Avenella flexuosa & 0.5092 & 1 & 5 & 0 & 100 & 80 \\
\hline Vaccinium vitis-idaea & 0.4333 & 9 & 9 & 0 & 100 & 0 \\
\hline Betula pubescens agg.-t1 & 0.4272 & 0 & 3 & 0 & 100 & 67 \\
\hline Polytrichum commune & 0.4151 & 7 & 8 & 0 & 100 & 13 \\
\hline Trientalis europaea & 0.3101 & 6 & 6 & 17 & 83 & 17 \\
\hline Calamagrostis villosa & 0.2580 & 5 & 8 & 0 & 100 & 38 \\
\hline Agrostis stolonifera & 0.2563 & 1 & 2 & 0 & 100 & 50 \\
\hline Vaccinium uliginosum & 0.2485 & 3 & 5 & 33 & 67 & 60 \\
\hline Molinia caerulea & 0.2357 & 1 & 2 & 0 & 100 & 50 \\
\hline Vaccinium myrtillus & 0.2279 & 8 & 9 & 0 & 100 & 11 \\
\hline Homogyne alpina & 0.2195 & 2 & 4 & 50 & 50 & 75 \\
\hline Carex echinata & 0.2085 & 2 & 3 & 50 & 50 & 67 \\
\hline Oxycoccus palustris & 0.1951 & 5 & 6 & 40 & 60 & 50 \\
\hline Carex nigra & 0.1723 & 5 & 8 & 0 & 100 & 38 \\
\hline Eriophorum vaginatum & 0.1721 & 5 & 8 & 0 & 100 & 38 \\
\hline Crepis paludosa & 0.1491 & 1 & 2 & 0 & 100 & 50 \\
\hline Betula carpatica & 0.1435 & 2 & 1 & 100 & 0 & 100 \\
\hline Melampyrum pratense & 0.1374 & 5 & 6 & 20 & 80 & 33 \\
\hline Viola palustris & 0.0995 & 2 & 2 & 50 & 50 & 50 \\
\hline Sphagnum magellanicum & 0.0833 & 3 & 5 & 33 & 67 & 60 \\
\hline Dicranum scoparium & 0.0819 & 2 & 3 & 100 & 0 & 100 \\
\hline Picea abies- $\mathrm{t} 1$ & 0.0624 & 9 & 9 & 0 & 100 & 0 \\
\hline Picea abies & 0.0586 & 6 & 6 & 17 & 83 & 17 \\
\hline Aulacomnium palustre & 0.0354 & 1 & 2 & 100 & 0 & 100 \\
\hline Equisetum sylvaticum & 0.0000 & 2 & 2 & 50 & 50 & 50 \\
\hline Polytrichum strictum & 0.0000 & 2 & 3 & 0 & 100 & 33 \\
\hline Carex rostrata & -0.0201 & 3 & 4 & 0 & 100 & 25 \\
\hline Drosera rotundifolia & -0.0671 & 1 & 3 & 0 & 100 & 67 \\
\hline Potentilla erecta & -0.0819 & 5 & 4 & 40 & 60 & 25 \\
\hline
\end{tabular}


Appendix A. (Continued)

\begin{tabular}{llllrrr}
\hline Sphagno-Piceetum & First axis scores & $1972 / 19741999$ & Retreated & Persisted & Emerged \\
\hline Pleurozium schreberi & -0.0885 & 6 & 6 & 33 & 67 & 33 \\
Bazzania trilobata & -0.0995 & 2 & 2 & 0 & 100 & 0 \\
Juncus effusus & -0.1200 & 2 & 2 & 100 & 0 & 100 \\
Sphagnum fallax & -0.2416 & 6 & 6 & 50 & 50 & 50 \\
Sphagnum russowii & -0.2964 & 3 & 6 & 33 & 67 & 67 \\
Deschampsia cespitosa & -0.3982 & 3 & 1 & 100 & 0 & 100 \\
\hline
\end{tabular}

\section{References}

Begon, M., Harper, J.L., Townsend, C.R., 1990. Ecology: Individuals, Populations and Communities. Blackwell, Boston.

Bohn, U., Gollub, G., Hettwer, C., 2000. Karte der natürlichen Vegetation Europas. Map of the Natural Vegetation of Europe. Maßstab/Scale 1:2500 000. Bonn-Bad Godesberg.

Brakenhielm, S., Persson, H., 1980. Vegetation dynamics in developing Scots pine stands in central Sweden. Ecol. Bull. 32, 139-152.

Braun-Blanquet, J., 1964. Pflanzensoziologie, 3rd ed., Springer Verlag, Wien-New York, p. 865.

Braun-Blanquet, J., Sissingh, G., Vlieger, J., 1939. Prodromus der Pflanzengesellschaften. 6. Klasse der Vaccinio-Piceetea, Montpellier.

Brzeziecki, B., Kienast, F., Wildi, O., 1995. Modelling potential impacts of climate change on the spatial-distribution of zonal forest communities in Switzerland. J. Veg. Sci. 611 (2), 257-268.

Buček, A., Kopecká, V., 2001. Trend posunů vegetačních stupňc̊ v důsledku možných globálních změn klimatu (Trend of vegetation belts shifts as result of possible global climate changes). In: Viewegh, J. (Ed.), Problematika lesnické typologie III. ČZU Praha, pp. 12-16 (in Czech).

Dahl, E., Hadač, E., 1941. Strandgesellschaften der Insel Ostøy im Oslofjord. Nytt. Mag. Naturvidensk., Oslo, 82, pp. 251-312.

Ehrendorfer, E., 1973. Liste der Gefässpflanzen Mitteleuropas. 2. Erweiterte Aufl. Gustav Fischer, Stuttgart.

Ellenberg, H. et al., 1992. Zeigerwerte von Pflanzen in Mitteleuropa 2. Auflage. Scripta Geobot. 18, 1-258.

Engelmark, O., Hofgaard, A., Arnborg, T., 1998. Successional trends 219 years after fire in an old Pinus sylvestris stand in northern Sweden. J. Veg. Sci. 9, 583-592.

Frahm, J.P., Frey, W., 1992. Moosflora, 3rd ed. E. Ulmer, Stuttgart.

Hadač, E., Březina, P., Ježek, V., Kubička, J., Hadačová, V., Vondráček, M., et al., 1969. Die Pflanzengesellschaften des Tales Dolina Siedmich prameňov in der Belaer Tatra. In: Vegetácia ČSSR, Ser. B, 2, Vydav. SAV Bratislava, p. 343.

Hartmann, F.K., 1953. Waldgesellschaften der deutschen Mittelgebirge und des Hügellandes. Akad. für Raumforsch. und Landesplanung, Hannover.

Hartmann, F.K., Jahn, G., 1967. Waldgesellschaften des mitteleuropäischen Gebirgsraumes nördlich der Alpen. Gustav Fischer, Stuttgart, p. 636.
Hladilin, V., 1996. Péče o lesní ekosystémy Národního parku Šumava (Management of forest ecosystems in the Šumava National Park). Silva Gabreta, Vimperk 1, 227-230 (in Czech).

Hofgaard, A., 1993. 50 years of change in Swedish boreal oldgrowth Picea abies forest. J. Veg. Sci. 4, 773-782.

Husová, M., Jirásek, J., Moravec, J., 2002. Jehličnaté lesy. Coniferous forests. In: Moravec, J. (Ed.), Přehled vegetace České republiky, vol. 3. Vegetation Survey of the Czech Republic, Praha, p. 128.

Jirásek, J., 1996. Společenstva přirozených smrčin České republiky. Gesellschaften natürlicher Fichtenwälder in der Tschechischen Republik. Preslia 67, 225-259.

Kopáček, J., Hejzlar, J., Kaňa, J., Porcal, P., 2001. Element budgets in three Bohemian Forest lakes and their watersheds in the 2000 hydrological year. I. Čertovo Lake. Silva Gabreta, Vimperk 6, 35-52.

Krajina, V., 1933a. Die Pflanzengesellschaften des Mlynica-Tales in den Vysoké Tatry (Hohe Tatra). Beih. Bot. Cbl., Sect. 2, vol. 50, pp. 774-957.

Krajina, V., 1933b. Die Pflanzengesellschaften des Mlynica-Tales in den Vysoké Tatry (Hohe Tatra). Beih. Bot. Cbl., Sect. 2, vol. 51, pp. 1-224.

Lähde, E., Nieppola, J., 1987. Vegetation changes in old stands of Pinus sylvestris L. in southern Finland. Scand. J. For. Res. 2, 369-377.

Lepš, J., Hadincová, V., 1992. How reliable are our vegetation analyses? J. Veg. Sci. 3, 119-124.

Majer, J., 2001. Vymezení smrčin na Šumavě (Delimitation of spruce forests in the Bohemian Forest). In: Viewegh, J. (Ed.), Problematika lesnické typologie III. ČZU Praha, pp. 72-75 (in Czech).

Malmer, N., Lindgren, L., Persson, S., 1978. Vegetational succession in a south Swedish deciduous wood. Vegetatio 36, 17-29.

Mánek, J., 1998. Vegetace a chemismus tekoucích vod horního Pootaví jako indikátory antropogenního zatížení (Vegetation and chemism of running waters in the upper part of the Otava catchment as indicators of anthropogenic impact). Silva Gabreta, Vimperk 2, 117-140 (in Czech with English summary).

Mikyška, R. (Ed.), 1968-1972. Geobotanická mapa ČSSR. I. České země. Geobotanische Karte der Tschechoslowakischen Sozialistischen Republik I. Tschechische Länder. NČSAV Praha, 21 map: color.

Neuhäuslová, Z., 2001. Poznámky ke klimaxovým smrčinám a smrkovým bučinám na vegetační mapě NP Šumava (Remarks to climax-spruce and spruce-beech forests on the vegetation 
map of the Šumava National Park). In: Viewegh, J. (Ed.), Problematika lesnické typologie III. ČZU Praha, pp. 66-71 (in Czech with English summary).

Neuhäuslová, Z., Eltsova, V., 2001. Das Sphagno-Piceetum im Nationalpark Šumava (Böhmerwald). Silva Gabreta 6, 111-124.

Neuhäuslová, Z., Eltsova, V., 2002. The Bazzanio-Piceetum in the Bohemian Forest (Šumava Mts.), Czech Republic. Feddes Repert. 113 (5-6), 367-379.

Neuhäuslová, Z., Sofron, J., Sádlo, J., Soukupová, L., Bufková, I., Vorel, J., 2002. Mapa potenciální přirozené vegetace NP Šmava (Map of potential natural vegetation of the Šumava National Park), 1 map. color. Botanical Inst. AS ČR Průhonice, Labor. GIS, Vimperk (in Czech).

Nygaard, P.H., Ødegaard, T., 1999. Sixty years of vegetation dynamics in a south boreal coniferous forest in southern Norway. J. Veg. Sci. 10, 5-16.

Økland, R.H., 1994. Bryophyte and lichen persistence patterns in a Norwegian boreal coniferous forest. Lindbergia 19, 50-62.

Økland, R.H., 1995. Changes in the occurrence and abundance of plant species in a Norwegian boreal coniferous forest, 19881993. Nord. J. Bot. 15 (4), 415-438.

Økland, R.H., Eilertsen, O., 1996. Dynamics of understorey vegetation in an old-growth boreal coniferous forest, 19881993. J. Veg. Sci. 7, 747-762.

Pecharová, E., Rada, P. (Eds.), 1995. Šumavské studie. BÚ AV ČR Třeboň, p. 112 (in Czech).

Petermann, R., Seibert, P., 1979. Die Pflanzengeselschaften des Nationalparks Bayerischer Wald mit einer farbigen Vegetationskarte. In: Nationalpark Bayerischer Wald 4. Bayer. Staatsministerium Ernährung, Landwirt. und Forsten, Grafenau.

Poelt, J., 1969. Bestimmungsschlüssel Europäischer Flechten. Lehre.

Schaumberg, J., 2000. Long-term trends in biology and chemistry of the acidified Bavarian Forest lakes. Silva Gabreta, Vimperk 4, 29-40.

Slavík, B. (Ed.), 2000. Květena České republiky 6. Academia, Praha, p. 770.

Sofron, J., 1969. Bibliografie Šumavy 1945-1967 (Bibliography of the Bohemian Forest). Plzeň and České Budějovice (in Czech).

Sofron, J., 1981. Přirozené smrčiny západních a jihozápadních Čech (Natürliche Fichtenwälder in West- und Südwestböhmen). Studie ČSAV Praha 7, 1-127.

Sofron, J., 1984. Bibliografie Šumavy 1968-1980 (a doplňky za rok 1945-1967) (Bibliography of the Bohemian Forest and supplements for years 1945-1967). I-IV, Sborn. Západočes. Muz. Plzeň Přír. 49A-D, PP. 1-404 (in Czech).

Sofron, J., 2000. Podnebí Šumavy (Climate of the Bohemian Forest). Ms. depon.-Musem of West Bohemia, Dept of Botany, Plzeň. (in Czech).

Sofron, J., Štěpán, J., 1971. Vegetace šumavských karů. Rozpr. Čs. Akad. Věd, Ser. math.-natur. 81 (1), 1-57 (in Czech with German summary).

Anonymous., 2000. SPSS 10.0 for Windows. SPSS Science, Chicago.

Staněk, J. (Ed.), 2002. 50 let Meteorologické stanice Churáňov (50 years of meteorological station Churáňov). ČHMÚ Praha, p. 105 (in Czech).

Sucharová, J., Suchara, I., 2001. Určení obsahu 30 prvků v mechu jako podklad pro stanovení relativní míry atmosférické depozice těchto prvků na území ČR, Tabulk. část (Determination of content of 30 elements in mosses as basis for determination of ratio of atmospheric deposition in the Czech Republic, Tables). Depon. VÚKOZ Průhonice, p. 84 (in Czech with English summary).

Szafer, W., Pawłowski, B., Kułczyński, S., 1923. Zespoły roślin w Tatrach. I. Zespoły roślin w dolinie Chochołowskiej. Die Pflanzenassoziationen des Tatra-Gebirges. I. Teil. Die Pflanzenassoziationen des Chochołowska-Tales. Bull. Acad. Polon. Sci. Lett., Cl. math.-natur., Sect. B, 1923, pp. 1-66 (Suppl. Cracovie).

Ter Braak, C.J.F., Gremmen, N.J.M., 1987. Ecological amplitudes of plant species and the internal consistency of Ellenberg's indicator values for moisture. Vegetatio 69, 79-87.

Ter Braak, C.J.F., Šmilauer, P., 1998. CANOCO Release 4. Reference Manual and User's Guide to Canoco for Windows: Software for Canonical Community Ordination. Microcomputer Power, Ithaca, NY.

Vacek, S., Lepš, J., 1991. Analýza vegetačních změn v bukových porostech Orlických hor (Analysis of vegetation changes in beech forests in Orlické hory Mts.). Lesnictví 12, 993-1007 (in Czech with English summary).

Vacek, S., Lepš, J., 1992. Analýza vegetačních změn ve smrkových porostech Orlických hor (Analysis of vegetation changes in spruce forests in Orlické hory Mts.). Lesnictvý 13, 733-749 (in Czech with English summary).

Vacek, S., Mayová, J., 2000. K problematice vegetační stupňovitosti NP Sumava. Problems of the altitudinal zonation of the vegetation in the Šumava National Park. In: Podrázský, V., et al. (Eds.), Monitoring, výzkum a management ekosystémů Národního parku Šumava, Kostelec n. Čer. Lesy, pp. 138-141 (in Czech with English abstract).

Vacek, A., Bastel, M., Lepš, J., 1999. Vegetation changes in forests of the Krkonoše Mts. over a period of air pollution stress (1980-1995). Plant Ecol. 143, 1-11.

van der Maarel, E., 1979. Transformation of cover-abundance values in phytosociology and its effects on community similarity. Vegetatio 39, 97-114.

Veselý, J., 1996. Změny složení vod šumavských jezer v letech 1984 až 1995 (Trends in acid-base status of acidified lakes in Bohemian Forest: 1984-1995). Silva Gabreta, Vimperk 1, 129141 (in Czech with English abstract).

Vinš, B., et al., 1996. Dopady možné změny klimatu na lesy v České republice (Impact of possible climate changes on the forests, Czech Republic). In: 19. Národní klimat. Program, Česká republika. Praha (in Czech).

Vrba, J., Kopáček, J., Fott, J., 2000. Long term limnological research of the Bohemian Forest lakes and their recent status. Silva Gabreta, Vimperk 4, 7-28.

Wamelink, G.W.W., Joosten, V., van Dobben, H.F., Berendse, F., 2002. Validity of Ellenberg indicator values judged from physico-chemical field measurements. J. Veg. Sci. 13, 269-278.

Zar, J.H., 1999. Biostatistical Analysis, 4th ed. Prentice-Hall. New Jersey.

Zelenková, E., et al., 2000. Plán péče Ná-rodního parku Šumava (Management of the National Park Šumava). National Park Šumava, Vimperk, pp. 98, 109, 140 (Suppl.) (in Czech). 